\title{
Normas de publicação para os colaboradores
}

\section{Quanto ao tipo de contribuição}

- Artigos inéditos (até 30 laudas de 30 linhas por 70 toques, ou aproximadamente 60.000 caracteres, incluindo referências bibliográficas e notas).

- Ensaios bibliográficos (até 12 laudas de 30 linhas por 70 toques, ou 25.200 caracteres, incluindo referências bibliográficas e notas): resenhas críticas de apenas um livro ou de vários livros tratando de assuntos correlatos.

- Resenhas bibliográficas (até 6 laudas de 30 linhas por 70 toques, ou 6.300 caracteres): pequenas resenhas de livros recentes.

\section{Quanto à avaliação da publicação}

- A revista publica artigos em português, inglês e espanhol, aceitando submissão em francês, cuja publicação estará condicionada à possibilidade de tradução.

- Os originais de artigos, ensaios e resenhas submetidos à revista são encaminhados para a apreciação de pelo menos dois pareceristas integrantes do Conselho Editorial, Comissão Editorial ou consultores ad hoc, levando em conta o perfil e a linha editorial da revista, além do conteúdo, da relevância e da qualidade das contribuições. Será garantido o anonimato de autores e pareceristas no processo de avaliação. Nesse processo, os originais são lidos inicialmente pelo Editor que, se considerar estarem de acordo com a política editorial, os remeterá para os pareceristas.

3. Cada artigo deve estar acompanhado por um resumo contendo entre 100 e 150 palavras, em português e em inglês, com palavras-chave. Os autores devem enviar seus dados profissionais (instituição, cargo, 
titulação, principais publicações), endereço para correspondência e e-mail. Estes dados devem aparecer ao final do trabalho.

4. As notas devem vir no rodapé, não podendo consistir em simples referências bibliográficas.

5. As citações e as referências bibliográficas devem aparecer no corpo do texto com o seguinte formato:

- (sobrenome do autor/espaço, ano de publicação, página), conforme o exemplo: (WAGLEY, 1977, p. 160-162).

6. As referências bibliográficas, em ordem alfabética, devem se encontrar após as notas e respeitar o formato que aparece nos seguintes exemplos (pede-se atenção a pontuação, espaços, negrito e uso de maiúscula):

- Livro:

VEBLEN, T. A teoria da classe ociosa. São Paulo: Livraria Pioneira, 1965.

- Coletânea:

LIPSET, S. M. (org.). Política e Ciências Sociais. Rio de Janeiro: Zahar, 1972.

- Artigo em coletânea:

WALLERSTEIN, I. Three Ideologies or One? The PseudoBattle of Modernity. In: TURNER, S. P. (org.). Social Theory \& Sociology. The Classics and Beyond. Oxford: Blackwell, 1996.

- Artigo em periódico:

PAIXÃO, A. L. A teoria geral da ação e a arte da controvérsia. Revista Brasileira de Ciências Sociais, São Paulo, v. 4, n. 11, p. 34-56, out.1989.

- Tese e dissertação acadêmicas:

MIGUEL, S. M. Um olhar para dentro: o movimento feminista no Rio de Janeiro. Florianópolis. Dissertação (Mestrado em Sociologia Política). Universidade Federal de Santa Catarina, 1988.

7. Os gráficos, quadros e mapas devem ser encaminhados em folhas separadas, numerados e titulados corretamente, com a devida 
referência e com indicação do local de sua inserção no texto. Devem estar confeccionados de maneira a permitir sua reprodução direta.

8. Com a publicação do artigo ou ensaio bibliográfico, o autor receberá dois exemplares da revista. No caso de resenhas, o autor receberá um exemplar da revista.

9. Os ensaios bibliográficos e resenhas devem apresentar a referência completa das obras analisadas, indicando o número de páginas de cada uma.

10. O envio de qualquer colaboração implica a cessão integral dos direitos autorais à revista Política \& Sociedade. Uma nova publicação do mesmo texto, de iniciativa de seu autor ou de terceiros, fica sujeita à expressa menção da precedência de sua publicação neste periódico, citando-se a edição e data dessa publicação. A revista não se compromete em devolver os originais das colaborações enviadas.

11. As opiniões expressas nos artigos assinados são de responsabilidade exclusiva de seus autores.

12. Os autores devem enviar seus textos em formato eletrônico (Word for Windows 97-2003 ou superior) para o endereço eletrônico ps@cfh. ufsc.br ou diretamente via site da revista (http://www.periodicos.ufsc. br/index.php/politica).

Para maiores informações, consultar o Programa de PósGraduação em Sociologia Política:

Tel. (48) 3721-9253

Fax (48) 3721-9098

Endereço eletrônico: ppgsp@cfh.ufsc.br

Portal eletrônico: http://www.sociologia.ufsc.br 